\title{
Effect of Public Service Quality on People Satisfaction toward Implementation of Integrated Administration Service Kecamatan in New Normal Era Kecamatan Sako Palembang City
}

\author{
Trecy Austin ${ }^{\mathrm{a}}$, Deby Chintia Hestiriniah ${ }^{\mathrm{b}} *$ \\ ${ }^{\mathrm{a}, \mathrm{b}}$ Department of Public Administration STISIPOL Candradimuka, Palembang, South Sumatera, Indonesia
}

\section{ARTICLE INFORMATION}

\section{Article history:}

Data submission : 10 June 2020

$1^{\text {st }}$ revision: 10 August 2020

Accepted: 16 November 2021

Available online: 10 December 2021

Keywords: public service, people satisfaction, integrated administration service.

\begin{abstract}
2020 is the year of the COVID-19 pandemic which made Government implement Large Scale Social Restriction Policy, both Social Distancing and Physical Distancing. However, based on the observation results made by the researcher in the field of the PATEN process in Kecamatan Sako during new normal, people were not yet discipline in dealing with online services. The services continue as usual by implementing strict health protocol such as to wash hands with soap often, to wear mask, to maintain a distance of a meter. Based on the survey conducted in Kecamatan Sako, the respondents still did stuff on the spot directly because the physical files still had to be collected at the PATEN counter to be processed. According to a direct interview conducted with the Head of the Government Section, the management of Family Card and ID card was carried out at the UPT Zone VIII of civil registration since April 23, 2020. The purposes of this study are to analyze the effect of service quality (tangibles, reliability, responsiveness, assurance, and empathy) on people satisfaction in Kecamatan Sako and to explain the dimensions of service quality (tangibles, reliability, responsiveness, assurance, and empathy), which dimensions have the most dominant influence on people satisfaction in Kecamatan Sako. This study uses quantitative methods. The method used in data collection is Proportionate Random Sampling. The data quality test consists of testing the validity and reliability of the data using multiple linear regression. The results of this study indicate that the $t$ value is 1.985 with a significant value of $0.015<0.05$, so that the results of the first problem formulation are Tangible, Assurance, and Empathy which have a significant effect on the variable of people satisfaction. The second problem formulation explains that the empathy variable is the variable that has the most dominant influence on the dependent variable or dependent (y) with the largest Beta value which is 0.551 .
\end{abstract}

2021 FIA UB. All rights reserved.

\section{Introduction}

However, whatever happens in 2020, the bureaucratic governance must still accommodate public services. In creating a bureaucracy, it must optimize the use of information and communication technology. The updates to the service system from face-to-face to electronic were carried out by all service officers to diminish the spread of the COVID-19 virus. In addition, bureaucratic service officers also cut down the office working hours, in which services are shorter. However, in Kecamatan Sako, the online system is not available because people still want to hand in files directly to the counter. Thus, this research addresses the following problems. First, new adaption for the community and service officers in the new normal era, offline to online. Second, tendency of the Indonesian people is still very dominant both in terms of state administrators and socialization to the public regarding access to services that must be online during the new normal period. Third, time or hours of service for service officers change after the new normal. Fourth, according to the ombudsman's research results, public services in Indonesia have not been able to provide clear information relating to the

* Corresponding author. Tel.: +62-812-222-33395; e-mail: trecy.austin@gmail.com 
flow and time frame for the completion of the complaint process.

Based on the identification of these problems, the problem of the study would be: How does service quality (tangibles, reliability, responsiveness, assurance, and empathy) have a significant effect on people satisfaction in PATEN services during the new normal. Which dimensions of service quality (tangibles, reliability, responsiveness, assurance, and empathy) are the most dominant that affects people satisfaction in PATENT services during the new normal?

\section{Theory}

\subsection{Public Service Quality}

Of the ten dimensions of service quality described by Zeithaml et al (in Tjiptono \& Diana, 2011), this is simplified into five dimensions, called Service Quality (SERVEQUAL) as in Table 1.

Table 1. Correspondence between servequal dimensions and original ten dimension for evaluating service quality

\begin{tabular}{|c|c|c|c|c|c|}
\hline $\begin{array}{l}10 \text { Original } \\
\text { Dimensions to } \\
\text { Evaluate } \\
\text { Service } \\
\text { Quality }\end{array}$ & $\begin{array}{c}\text { Tangib } \\
\text { les }\end{array}$ & $\begin{array}{c}\text { Reliabi } \\
\text { lity }\end{array}$ & $\begin{array}{c}\text { Responsi } \\
\text { veness }\end{array}$ & $\begin{array}{c}\text { Assura } \\
\text { nce }\end{array}$ & $\underset{\text { ty }}{\text { Empha }}$ \\
\hline \multicolumn{6}{|l|}{ Tangible } \\
\hline \multicolumn{6}{|l|}{ Reliability } \\
\hline \multicolumn{6}{|l|}{ Responsiveness } \\
\hline \multicolumn{6}{|l|}{ Competence } \\
\hline Courtesy & & & & & \\
\hline \multicolumn{6}{|l|}{ Ceredibility } \\
\hline \multicolumn{6}{|l|}{ Security } \\
\hline \multicolumn{6}{|l|}{ Access } \\
\hline \multicolumn{6}{|l|}{ Communication } \\
\hline $\begin{array}{l}\text { Understan } \\
\text { ding the } \\
\text { Customer }\end{array}$ & & & & & \\
\hline
\end{tabular}

Source: processed by the author in 2019

The SERVQUAL concept initially includes ten dimensions, but it is simplified into five dimensions such as tangible, reliability, responsiveness, assurance and empathy (Hardiansyah, 2018). These five dimensions have their indicators discussed in the research methods for each.

\subsection{People Satisfaction}

Satisfaction is derived from the Latin "satis" (meaning good enough, adequate) and "facio" (doing or making).
Satisfaction can be defined as "an effort to fulfill something" or "to make something adequate". Haryanto (2013) describes the meaning of satisfaction as "the good feeling that you have when you achieved something or when something that you wanted to happen does happen"; "the act of fulfilling a need or desire"; dan "an acceptable way of dealing with a complaint, a debt, an injury, etc." The people satisfaction index, according to the ministerial decree PAN No. 25 of 2004, there are 14 things related to performance and service (Ibrahim, 2008, Rezha et al., 2018).

\subsection{Integrated Administration Services of Kecamatan}

Regulation of the Minister of Home Affairs, article 3 Number 4 of 2010 concerning Guidelines for Integrated Administration Services of Kecamatan says "to make Kecamatan as a service center for people and a service for integrated service offices/agencies in the regency/city" (Mulyadi, \& Zahro, 2018). Public service administrator in Kecamatan from the application stage to the publication stage of documents is in one place. One place here means that the service is done at only one counter/service desk. The scope of the Integrated Administrative Services of Kecamatan (PATEN) is service in the licensing sector and service in the nonlicensing sector.

\subsection{New Normal Era}

Ratnah and Muljadi (2019) explain new normal is a change of behavior to continue normal activities as usual. New normal cannot be implemented without any preparation. There are five stages that must be taken by the area that is heading to New Normal. Stage one] is a precondition. Each region must reveal the preconditions for implementing the new normal by providing information that is clear, holistic, and understandable by the people. This stage must be completed by actions to prevent and handle COVID-19 by giving socialization and effective public communication. Stage two is the timing stage. This stage determines the time when an area can start its social and economic activities. Stage 3 is priority stage. this stage is done to designate regions or sectors that are allowed to start social and economic activities gradually to stage four is Central and Regional Coordination Stage. In this stage, there is the reciprocal consultation between the central government and local governments in making decisions related to the implementation of the New Normal. Stage five is monitoring and evaluation stage of the implementation of the recovery of socio-economic activities.

\subsection{Hypothesis}

H0: There is no effect of service quality on the satisfaction of the community using PATEN services.

H1: There is a effect of service quality on the satisfaction of the community using PATEN services. 


\section{Research Method}

The research method used is quantitative method (Arikunto, 2010). The kelurahan selected as the sample area are: Sako, Sukamaju, Sialang dan Sako Baru. The data are related to the making of Family Card in Kecamatan Sako in 2019. The population in this study is 20.273 families. To figure out the sample of obtained population, the researcher uses Taro Yamane and Slovin formulas. There are two hypotheses formulated in this study to answer the problem of the study based on framework of thought. The first hypothesis is that the level of public service quality has an effect on people satisfaction. The second hypothesis is that the level of public service quality has no effect on people satisfaction. Data collection techniques used were questionnaire, observation, documentation, and literature. The type of scale used in this study is a Likert scale. The scales in this study are as follows $1=$ Very bad, 2 = bad, 3 = Good Enough $/$ Quite Satisfied, 4 = Good, and 5 = Very Good (Riduwan, \& Kuncoro, 2008).

\section{Results}

The testing is carried oud by validity and reliability tests. The first results of the validity test with the five variables (Tangible, Reliability, Responsiveness, Assurance, and Empathy) tested on 100 respondents showed that five items tested are valid. Instrument reliability testing is used to determine the consistency of measuring instrument. Instrument reliability test results from each variable obtained is acquired from the results of data processing with Cronbach alpha calculations at SPSS 25.00. The reliability testing is only for questions that are valid in the previous test. The question is called a reliability value if: Cronbach alpha value $\geq 0.6$, then it is reliable. If the Cronbach alpha value $<0.6$, then it is not reliable. Cronbach alpha test per statement items show all items are reliable.

Multiple linear regression analysis used in this study aims to estimate the regression coefficient which will indicate the influence of several dependent variables. The results of multiple linear regression analysis can be seen in Table 2 .

Table 2. Results of multiple linear regression analysis

\begin{tabular}{|c|c|c|c|c|c|c|}
\hline \multicolumn{7}{|c|}{ Coefficients $^{a}$} \\
\hline \multirow[b]{2}{*}{ Mode } & & \multicolumn{2}{|c|}{ Unstandardized Coefficients } & \multirow{2}{*}{$\begin{array}{c}\text { Standardized } \\
\text { Coefficients } \\
\text { Beta } \\
\end{array}$} & \multirow[b]{2}{*}{$t$} & \multirow[b]{2}{*}{ Sig. } \\
\hline & & B & Std. Error & & & \\
\hline \multirow[t]{6}{*}{1} & (Constant) & 10.946 & 2.935 & & 3.730 & .000 \\
\hline & TANGIBLE & .511 & .159 & .216 & 3.218 & .002 \\
\hline & REALIABLE & .246 & .241 & .081 & 1.021 & .310 \\
\hline & RESPONSIVNESS & -.540 & .255 & -.179 & -2.117 & .037 \\
\hline & ASSURANCE & .772 & .219 & .307 & 3.531 & .001 \\
\hline & EMPATHY & 1.480 & .212 & .551 & 6.968 & .000 \\
\hline
\end{tabular}

Based on the comparison of the significance value of five variables, it is known that only Reliability and
Responsiveness is smaller than 0.05. Thus, it is concluded that only the Reliability and Responsiveness dimension can be used to predict changes of people satisfaction. The value of the regression coefficient is in column B (Unstandardized Coefficient), so the equation for the regression line becomes: $\mathrm{Y}=10,946+0,511 \mathrm{x} 1+$ $0,246 \times 2-0,540 \times 3+0,772 \times 4+1,480 \times 5$.

Hypothesis testing 1 (H1) to hypothesis 5 (H5) uses the $t$ value in the SPSS calculation compared to the $t$ table value and the $t$ table $(\alpha / 2 ; \mathrm{n}-\mathrm{k}-1)$ where the value of $\alpha=$ level of trust is $0.05 . \mathrm{n}=$ number of respondents is 100 and $k=$ number of independent variables is 5 . Therefore, the $t$ table value obtained is $t(0.025$; 94) $=$ 1.985. The decision of acceptance or rejection of the hypothesis is by comparing the $t$ value to the $t$ table value. This decision follows the following conditions: If the $t_{\text {value }}>t$ table, then the hypothesis is accepted. If the $t$ value $<t$ table, then the hypothesis is rejected.

From these calculations, it can be concluded that the tangible, assurance, and empathy variables are above 1.985, which means that these variables have a significant effect on the people satisfaction variable, while Reliability and Responsiveness have no effect on people satisfaction. Finding out the service quality variable that has the most dominant effect on people satisfaction is determined by the beta value. Table 3 below is the beta value of the test results of each independent variable.

Table 3. Beta value of independent variables

\begin{tabular}{llc}
\hline No. & Variables & Beta value \\
\hline 1 & Tangible & 0.216 \\
2 & Reliability & 0.081 \\
3 & Responsiveness & -0.179 \\
4 & Assurance & 0.307 \\
5 & Empathy & 0.551 \\
\hline
\end{tabular}

Source: Primary Data Processing Results, 2020

It shows that the empathy variable has the largest Beta value that is 0.551 . This value indicates that the empathy variable is the variable that has the most dominant effect on the dependent variable (y). Thus, it can be concluded that the people's perception of the sincere and personal attention given to the people by trying to understand their desire has the most dominant effect on people satisfaction in implementing PATEN in Kecamatan Sako, Palembang City.

Simultaneous significance test or F statistical test is done to determine whether service quality variables including tangible, reliability, responsiveness, assurance, and empathy have effect on people satisfaction. Testing the sixth hypothesis by looking at $\mathrm{F}$ value in SPSS and compared to the value of $F$ table $=F(k$; $n-k)$ where the value of $k$ is the number of independent variables and $n$ is the number of respondents. Then the value of $F_{\text {table }}(5 ; 95)=2.31$ is obtained. The test is rejected or accepted by the hypothesis based on the 
following conditions: If the value of $\mathrm{F}_{\text {value }}>\mathrm{F}$ table, then the hypothesis is accepted. If the value of $F$ value $<F$ table, then the hypothesis is rejected. The following are the results of the calculation of $F$ value on SPSS in the Table 4.

\begin{tabular}{|c|c|c|c|c|c|c|}
\hline \multicolumn{7}{|c|}{ Table 4. F-test } \\
\hline Model & & $\begin{array}{l}\text { Sum of } \\
\text { Squares }\end{array}$ & $d f$ & Mean Square & $\mathrm{F}$ & Sig. \\
\hline \multirow[t]{3}{*}{1} & Regression & 3765.712 & 5 & 753.142 & 51.618 & $.000^{\mathrm{b}}$ \\
\hline & Residual & 1371.528 & 94 & 14.591 & & \\
\hline & Total & 5137.240 & 99 & & & \\
\hline \multicolumn{7}{|c|}{ a. Dependent Variable: KEPUASAN MASYARAKAT } \\
\hline & $\begin{array}{l}\text { ictors: (Cons } \\
\text { JRANCE }\end{array}$ & PAT & & & & \\
\hline
\end{tabular}

From the SPSS calculation above, it can be concluded that the $F$ value is $51.618>2.31$, so the research decision is to accept the hypothesis that there is an effect of tangible, reliability, responsiveness, assurance and empathy simultaneously on people satisfaction. The coefficient of determination in this study is used to test the goodness-fit) of a regression model. The coefficient of determination is determined by the adjusted $\mathrm{R}$ square value. The results of the determination coefficient test are as shown in the table below. It is figured out that the coefficient of determination (adjusted R Square) is 0.856 , this means that the effect of Tangible, Reliability, Responsiveness, Assurance and Empathy variables simultaneously on the people satisfaction variable is $73,3 \%$.

\section{Discussion and conclusion}

How does Service Quality (tangibles, reliability, responsiveness, assurance, and empathy) have a significant effect on people satisfaction in PATEN services during the New Normal? From the calculations, it can be concluded that the Tangible, Assurance, and Empathy variables are above 1,985 , which means that these variables have a significant effect on people satisfaction variable, while Reliability and Responsiveness have no effect on people satisfaction.

Which dimensions of service quality (tangibles, reliability, responsiveness, assurance, and empathy) are the most dominant that affects people satisfaction in PATENT services during the New Normal? This shows that the empathy variable has the largest Beta value, 0.551 . This value indicates that the empathy variable is the variable that has the most dominant influence on the dependent variable (y). Thus, it can be concluded that the public perception of the sincere and personal attention given to the people by trying to understand their desires has the most dominant effect on people satisfaction in implementing PATEN in Kecamatan Sako, Palembang City.

The suggestions that can be given by the author based on the research results. First, It is recommended that the implementer should be more strict in terms of washing hands using soap, and there should be the availability of temperature measurements in front of the service building. Second, in the future, the sako office make more use of technology with the availability of virtual and digital meeting rooms. Employees also can take advantage of this special meeting room for education activities, and training. Third, Kecamatan Sako should coordinate with the OSS institution of the Investment Coordinating Board. It also needs to have electronically integrated Licensing Service, especially for trading business license services.

\section{References}

Arikunto, S. (2010). Prosedur Penelitian Suatu Pendekatan Praktek (Edisi Revisi 2010). Rineka Cipta.

Hardiansyah. (2018). Kualitas Pelayanan Publik. Gava Media.

Haryanto, E. (2013). Kualitas Layanan, Fasilitas dan Harga Pengaruhnya terhadap Kepuasan Pengguna Jasa Layanan pada Kantor Samsat Manado. Jurnal EMBA. 1(3) 2302-1174.

Ibrahim, A. (2008). Teori dan Konsep Pelayanan Publik serta implementasinya. Refika Aditama.

Mulyadi, \& Zahro, S. (2018). Pengaruh Disiplin dan Layanan Publik terhadap Kepuasan Masyarakat di Kelurahan Muara Kulam Kecamatan Ulu Rawas Kabupaten Musi Rawas Utara. 4(2) 2527-7243.

Ratnah, R. \& Muljadi. (2018). Pengaruh Tangible dan Responsiveness terhadap Kepuasan Wajib Pajak Kendaraan Bermotor Pada Layanan SAMSAT Keliling Balaraja Kabupaten Tangerang Banten. Jurnal Perilaku dan Strategi Bisnis, 6(1) 4-19.

Rezha, F, Rohmah, S. \& Siswidiyanto. (2018). Analisis Pengaruh Kualitas Pelayanan Publik terhadap Kepuasan Masyarakat. Studi tentang pelayanan perekaman Kartu Tanda Penduduk Elektronik (eKTP) di Kota Depok. Jurnal Administrasi Publik (JAP), 1(5) 981-990.

Riduwan, \& Kuncoro, E.A. (2008). Cara Menggunakan dan Memakai Analisis Jalur (Path Analysis). Alfabeta.

Tjiptono, F. \& Diana, A. (2011). Service, Quality \& Satisfaction. Andi. 